Reviu Akuntansi dan Bisnis Indonesia, Vol. 3 No. 1, Hlm: 1-13, Juli 2019

Website: http://journal.umy.ac.id/index.php/rab

\title{
Pengaruh Kepemilikan Saham dan Leverage Terhadap Agresivitas Pajak Perusahaan
}

\author{
Ghaisani Alfira Nugraheni *; Alek Murtin \\ Program Studi Akuntansi Univeritas Muhammadiyah Yogyakarta.
}

\section{N F O A R T I K E L}

\section{Kata Kunci:}

Corporate Tax

Aggressiveness, Institutional

Ownership, Managerial

Ownership, Public

Ownership, Leverage.

Jenis Artikel:

Penelitian Empiris

Correspondence:

ghaisani.alfira@gmail.com

\author{
A B S T R A K
}

Many taxpayer in Indonesia did tax aggresiveness, especially corporate taxpayer of $80 \%$. This is proven survey reported by IMF investigator in 2016, that Indonesia ranks 11 th out of 30th countries on tax aggressiveness carried out by the company. Tax aggressiveness is an action to minimize tax burden by conducting tax planning which could be legal or illegal. Tax aggressiveness can measured with Effective Tax Rate (ETR). This research aimed to examine the effect of share ownership and leverage toward corporate tax aggressiveness. This population in this study is the listed manufacturing companies in Indonesian Stock Exchange in 2015 until 2017. The sample was determained by the nonprobability sampling method purposive sampling technique, so 33 maufacturing companies have been selected as research sample. Type of data used was secondary data obtained from www.idx.co.id. The method of analysis used is multiple regression analysis by using SPSS version 15.0. The result of research show that institutional ownership and public ownership have negative significant effect toward corporate tax aggressiveness. Managerial ownership and leverage have no effect toward corporate tax aggressiveness. Adjusted R Square value of institutional ownership, managerial ownership, public ownership, and leverage toward tax aggressiveness is $7,4 \%$.

(C) 2019 RAB. Published by Universitas Muhammadiyah Yogyakarta

\section{PENDAHULUAN}

Pembangunan nasional dilakukan pemerintah secara terus menerus guna peningkatan kesejahteraan rakyat Indonesia. Pemerintah telah melakukan berbagai upaya demi memajukan perekonomian Indonesia, seperti melakukan peningkatan penerimaan pajak. Pajak menyumbang lebih dari 75\% untuk pendapatan atau penerimaan negara. Namun, akhir-akhir ini penerimaan negara kurang maksimal yang diakibatkan oleh beberapa faktor. Salah satu faktor penyebabnya adalah kurangnya kesadaran wajib pajak untuk membayarkan pajaknya. Menurut Suara.com (2017), mayoritas pelaku penghindaraan pajak adalah wajib pajak badan dengan prosentase hingga 80\%. Setiap tahunnya, terdapat Rp 110 triliun kerugian pajak dari penghindaran pajak yang dilakukan wajib pajak.

Agresivitas pajak merupakan perencanaan pajak dengan mengurangi jumlah pajak yang dibayarkan secara legal muapun ilegal yang dilakukan oleh wajib pajak orang pribadi maupun badan. Di Indonesia, banyak wajib pajak badan melakukan penghindaran pajak dengan cara tax planning atau agresivitas pajak. DJP sangat mengharapkan perusahaan-perusahaan di Indonesia terutama perusahaan-perusahaan dari sektor manufaktur tidak melakukan penghindaran pajak (Astuti dan Aryani, 2016). Karena perusahan dari sektor inilah yang mengalami pertumbuhan 
terbesar di Indonesia. Namun, dengan adanya kenaikan tersebut tidak dapat menjamin bahwa perusahaan sektor manufaktur tidak melakukan penghindaran pajak.

Pada rentang waktu 2002-2006 terjadi kasus penghindaran pajak yang dilakukan oleh PT. Coca-Cola Indonesia (CCI). PT. Coca-Cola Indonesia mengklaim bahwa penghasilan kena pajak mereka hanya sebesar Rp 492,59 miliar. Namun, Dirjen Pajak menyatakan bahwa penghasilan kena pajak yang dimiliki PT. Coca-Cola Indonesia sebesar Rp 603,48 miliar. Menurut Kompas.com (2014), Dirjen Pajak menemukan adanya kenaikan jumlah beban usaha yang sangat besar. Selain itu, Dirjen pajak juga menemukan adanya kegiatan mencurigakan yang terjadi pada perusahaan tersebut, yaitu kegiatan transfer pricing, yang merupakan kegiatan pemindahan barang atau jasa antar beberapa divisi pada satu kelompok usaha dengan harga yang tidak wajar.

Dilakukannya penghindaran pajak tidak jauh dari peran manajer pada perusahaan. Tak sedikit manajer perusahaan melakukan perencanaan pajak untuk mengurangi pembayaran pajak. Terkadang perencanaan pajak yang dilakukan perusahaan masih dapat ditolerir (tax avoidance), namun juga ada yang tidak bisa ditolerir (tax evasion) karena telah melanggar hukum. Perusahaan yang ketahuan melanggaran hukum, akan dikenai sanksi perpajakan yaitu dengan membayar denda. Jumlah pajak yang dibayarkan akan lebih banyak dari yang semestinya.

Tidak sedikit manajer perusahaan melakukan perencanaan pajak demi laba perusahan. Namun, kebijakan-kabijakan yang diambil oleh menajer perusahaan ternyata selalu diawasi oleh pihak luar, seperti pihak pemegang saham. Pemegang saham merupakan orang atau badan yang memiliki saham di suatu perusahaan. Pemegang saham memiliki hak untuk memperoleh keuntungan yang sebanding dengan jumlah saham yang dimiliki, sehingga mereka harus selalu memperhatikan kelangsungan hidup perusahaan (Hadi dan Mangoting, 2014).

Pemegang saham dapat berasal dari institusi, manajerial, maupun publik. Kepemilikan institusi dapat berfungsi sebagai pengawas manajer dalam pengambilan keputusan, seperti keputusan dalam perencanaan pajak yang agresif. Adanya pemegang saham oleh institusi, diyakini akan mengurangi keputusan manajer untuk melakukan pajak agresif. Kepemilikan menejerial dimungkinkan dapat meningkatkan perencanaan pajak yang agresif pada suatu perusahaan. Karena dengan mengurangi beban pajak, akan menaikkan laba. Jika laba perusahaan meningkat, maka pihak manajemen akan memperoleh bonus karena telah berhasil meningkatkan laba perusahaan. Kepemilikan publik menginginkan jika perusahaan tidak melakukan agresif pajak. Karena masyarakat merasa pajak yang seharusnya dikeluarkan perusahaan dapat dimanfaatkan untuk kepentingan umum, yaitu membiayai fasilitas-fasilitas negara. Oleh sebab itu, dengan adanya kepemilikan publik akan menekan manajer untuk tidak melakukan pajak yang agresif.

Perencanaan pajak yang biasa digunakan oleh perusahaan adalah dengan meningkatkan hutang. Karena hutang yang dimiliki nantinya menimbukan adanya bunga yang harus dibayarkan perusahaan. Beban bunga ini dapat mengurangi laba perusahaan dan akhirnya dapat mengurangi beban pajak perusahaan. Jika perusahaan memiliki jumlah hutang yang tinggi, maka perusahaan tersebut terindikasi agresif terhadap perencanaan pajak.

Sesuai penjelasan diatas, terdapat fenomena konflik kepentingan yang terjadi antara pemegang saham dan manajer perusahaan. Pemegang saham dapat berasal dari institusi, manajerial, maupun publik. Konflik tersebut dilakukan oleh manajer perusahaan yaitu mengorbankan kepentingan pemegang saham demi kepentingan pribadi manajer. Salah satu hal yang dilakukan manajer adalah mengurangi jumlah pajak perusahaan. Selain itu, manajer juga dapat meningkatkan jumlah hutang perusahaan agar pajak yang harus dibayarkan berkurang. Semakin sedikit pembayaran pajak perusahaan, maka perusahaan tersebut terindikasi agresif dalam perpajakan.

Penelitian ini merupakan kompilasi dari penelitian yang dilakukan oleh Atari et al. (2016), Fadli (2016) dan Puspita dan Harto (2014). Perbedaan dari penelitian terdahulu terletak pada variabel independen yaitu kepemilikan publik, hal tersebut dikarenakan variabel kepemilikan publik masih jarang diteliti mengenai hubungannya terhadap agresivitas pajak. Proxy pada penelitian ini menggunakan ETR (Effective Tax Rate). Selain itu, objek pada penelitian ini adalah perusahaan dari sektor manufaktur. Karena masih banyak perusahaan dari sektor tersebut melakukan penghindaran pajak. Berdasarkan penjelasan diatas, penelitian ini bertujuan untuk 
meneliti pengaruh kepemilikan institusional, kepemilikan manajerial, kepemilikan publik dan leverage terhadap agresivitas pajak perusahaan manufaktur.

\section{TINJAUAN LITERATUR DAN PERUMUSAN HIPOTESIS}

\section{Teori Agensi}

Teori agensi menurut Jensen dan Meckling (1976) adalah kontrak antara satu atau beberapa individu yaitu sebagai prinsipal guna memberikan wewenang kepada agen untuk terlibat dalam pengambilan keputusan demi menjalankan perusahaan. Dalam hal ini, prinsipal adalah para pemegang saham, sedangkan agen merupakan manajer yang bertugas sebagai pengendali perusahaan. Agen harus menjalankan tugas yang diberikan oleh prinsipal atas tanggung jawabnya.

Pemegang saham dan manajer memiliki tujuan yang sama yaitu menginginkan laba sebesarbesarnya dan juga menghindari risiko yang akan terjadi. Agen yang memiliki lebih banyak informasi dibanding prinsipal memiliki kesempatan untuk pengambilan keputusan demi kepentingan pribadi. Agen akan mengambil keputusan yang menguntungakannya tanpa memberikan manfaat kepada prinsipal (Sari et al., 2017).

Perbedaan kepentingan yang terjadi antara agen dan prinsipal menyebabkan konflik keagenan. Konflik tersebut dapat menyebabkan pengaruh pada kinerja perusahaan.

\section{Pajak}

Pengertian pajak menurut Undang-Undang Nomor 16 tahun 2009 tentang Ketentuan Umum dan Tata Cara Perpajakan (Pasal 1 ayat 1) adalah kontribusi wajib kepada negara yang terutang oleh orang pribadi atau badan yang bersifat memaksa berdasarkan Undang-Undang, dengan tidak mendapatkan imbalan secara langsung dan digunakan untuk keperluan Negara bagi sebesarbesarnya kemakmuran rakyat. Subjek pajak merupakan pihak yang dikenai pajak atas penghasilan yang diterima, atau yang biasa disebut wajib pajak. Menurut Direktorat Jenderal Pajak Kementerian Keuangan (2019), adapun yang termasuk subjek pajak adalah orang pribadi, badan, warisan yang belum terbagi, serta Bentuk Usaha Tetan (BUT).

Subjek pajak terbagi menjadi dua, yaitu subjek pajak dalam negeri dan luar negeri. Subjek pajak dalam negeri terdiri dari orang pribadi, badan, dan warisan. Subjek pajak ini akan dikenai pajak apabila telah menerima penghasilan dari Indonesia maupun luar Indonesia. Sementara itu, subjek pajak luar negeri terdiri dari orang pribadi, badan dan bentuk usaha tetap (BUT). Subjek ini akan dikenai pajak apabila hanya menerima penghasilan yang bersumber dari Indonesia (Mardiasmo, 2009).

Selain subjek pajak, unsur dari pajak yaitu objek pajak. Yang menjadi objek pajak yaitu penghasilan. Maksud dari penghasilan disini yaitu setiap tambahan ekonomis yang diperoleh wajib pajak, baik dari Indonesia maupun luar negeri, yang dapat digunakan untuk konsumsi atau menambah kekayaan yang bersangkutan, dengan nama dan bentuk apapun. Selain itu, yang termasuk objek pajak adalah gaji, upah, tunjangan, honorarium, bonus, uang pensiun, komisi, gratifikasi, hadiah dari undian atau pekerjaan atau penghargaan, laba usaha, serta keuntungan atas penjualan atau pengalihan harta (Direktorat Jenderal Pajak Kementerian Keuangan, 2019).

\section{Agresivitas Pajak}

Menurut Frank et al. (2009), agresivitas pajak merupakan tindakan yang dilakukan wajib pajak untuk mengurangi beban pajak melalui perencanaan pajak dengan menggunakan cara yang tergolong atau tidak tergolong dalam pelanggaran pajak. Agresivitas pajak adalah suatu stretegi untuk mengurangi beban pajak perusahaan dengan penghindaran pajak yang melanggar peraturan atau memanfaatkan celah hukum (Hadi dan Mangoting, 2014). 
Agresivitas dapat diukur dengan beberapa cara, yaitu ETR (Effective Tax Rate), CETR (Cash Effective Tax Rate), dan BTD (Book Tax Difference). ETR yaitu pembagian antara beban pajak dengan laba sebelum pajak. Proksi CETR dihitungan dengan membagi jumlah pajak yang dibayarkan dengan laba sebelum pajak.

\section{Perumusan Hipotesis}

1. Pengaruh Kepemilikan Institusional terhadap Agresivtas Pajak

Kepemilikan institusional adalah proporsi saham perusahan yang dimiliki oleh institusi, baik institusi pemerintah maupun institusi swasta (Oktaviana dan Wahidahwati, 2017). Institusi tersebut antara lain perusahaan investasi, asuransi, bank, reksadana, dana pensiun, dan sebagainya.

Kepemilikan institusional dapat bertindak sebagai pengawas pada suatu perusahaan. Mereka akan mengawasi manajer perusahaan dalam pengambilan keputusan. Dengan adanya pengawasan dari pihak eksternal, maka dapat mengurangi konflik keagenan. Kepemilikan institusional dapat memperkecil adanya konflik kepentingan, misalnya memperkecil rencana manajer dalam menghindari/mengurangi pajak.

Penelitian yang dilakukan oleh Novitasari et al. (2017), menemukan bahwa kepemilikan institusional berpengaruh positif terhadap agresivitas pajak. Akan tetapi, Atami et al. (2017) menemukan hasil bahwa kepemilikan institusional berpengaruh negatif terhadap agresivitas pajak. Nugroho dan Firmansyah (2017) juga menemukan bahwa kepemilikan institusi berpengaruh negatif terhadap praktik pajak agresif. Fadli (2016) menemukan bahwa kepemilikan institusional tidak berpengaruh terhadap agresivitas pajak. Berdasarkan penjelasan diatas, maka hipotesis pada penelitian ini adalah:

\section{$\boldsymbol{H}_{\boldsymbol{I}} \quad$ : Kepemilikan institusional berpengaruh negatif terhadap agresivitas pajak.}

\section{Pengaruh Kepemilikan Manajerial terhadap Agresivtas Pajak}

Menurut Herdianti dan Husaini (2018), kepemilikan manajerial adalah proporsi saham yang dimiliki oleh direksi dan dewan komisaris selaku menejemen puncak. Kepemilikan manajerial merupakan proporsi saham biasa yang dimiliki oleh pihak manajemen yang terlibat dalam pengambilan keputusan perusahaan. Pada kepemilikan manajerial, manajer tidak hanya berperan sebagai pengelola namun juga sebagai pemegang saham. Pengelola maupun pemegang saham menginginkan perusahaan memperoleh laba yang tinggi. Selain itu, apabila manajer berhasil mengelola perusahaan sehingga memperoleh laba yang cukup tinggi, maka manajer juga akan memperoleh bonus atas apa yang telah mereka kerjakan.

Oleh karena itu, manajer memiliki kesempatan untuk memperoleh laba yang lebih banyak. Agar laba perusahaan lebih banyak dan manajerial memperoleh bonus yang banyak juga, maka manajer akan menggunakan cara-cara untuk memangkas beban yang dapat menaikkan nilai laba. Salah satu caranya yaitu dengan mengurangi jumlah beban pajaknya. Manajer akan melakukan pengurangan jumlah pajak demi menaikkan laba perusahaan (Sari et al., 2017).

Semakin banyak saham yang dimiliki manajerial, maka semakin tinggi juga tindakan manajer agresif dalam perpajakan. Penelitian yang dilakukan oleh Atari (2016) menghasilkan bahwa kepemilikan manajerial memiliki pengaruh positif terhadap agresivitas pajak. Rohmansyah (2017) menemukan bahwa kepemilikan manajerial dengan arah positif berpengaruh pada agresivitas pajak. Sementara itu, menurut Novitasari et al. (2017), kepemilikan manajerial tidak berpengaruh terhadap pajak agresif. Berdasarkan penjelasan diatas, maka hipotesis pada penelitian ini adalah:

\section{$\boldsymbol{H}_{2} \quad$ : Kepemilikan manajerial berpengaruh positif terhadap agresivitas pajak.}




\section{Pengaruh Kepemilikan Publik terhadap Agresivtas Pajak}

Kepemilikan publik merupakan proposi saham perusahaan yang dimiliki oleh pihak luar atau masyarakat luas, dimana prosentase kepemilikan saham dibawah 5\%. Masyarakat menginginkan perusahaan membayarkan pajak dengan benar. Meskipun sebagai pemegang saham, namun mereka mengharapkan perusahaan tidak melakukan penghindaran pajak. Karena mereka khawatir jika perusahaan ketahuan melakukan penghindaran pajak, nilai saham perusahaan akan turun. Oleh karena itu, masyarakat tidak menuntut manajemen menjadi ambisi dalam melakukan perencanaan pajak. Semakin banyak saham yang dimiliki oleh masyarakat, maka perusahaan tidak agresif dalam perpajakan.

Penelitian yang dilakukan oleh Puspita dan Harto (2014) menemukan bahwa kepemilikan publik memiliki pengaruh negatif pada penghindaran pajak. Sementara itu, Oktaviana dan Wahidahwati (2017) menemukan bahwa kepemilikan publik berpengaruh positif terhadap agresivitas pajak. Berdasarkan penjelasan diatas, maka hipotesis pada penelitian ini adalah:

\section{$\boldsymbol{H}_{3} \quad$ : Kepemilikan publik berpengaruh negatif terhadap agresivitas pajak.}

\section{Pengaruh Leverage terhadap Agresivtas Pajak}

Leverage merupakan rasio yang digunakan untuk mengukur seberapa jauh kemampuan perusahaan menggunakan hutang dalam pembiayaan aset yang dimilikinya (Ngadiman dan Puspitasari, 2014). Untuk menaikkan nilai liabilitas, dapat dilakukan dengan memperbesar hutang perusahaan. Tidak sedikit perusahaan dengan sengaja menaikkan hutang untuk mengurangi beban pajaknya. Karena nilai leverage yang besar, akan menimbulkan beban pajak yang harus dibayarkan menjadi sedikit. Semakin tinggi nilai leverage, maka semakin tinggi pula tindakan agresivitas pajak yang dilakukan perusahaan.

Pada hasil penelitian yang dilakukan oleh Suroiyah dan Khairani (2018) menemukan bahwa dengan arah positif leverage berpengaruh signifikan terhadap agresivitas pajak. Purwanto (2016) juga menemukan leverage memiliki pengaruh positif terhadap agresivitas pajak. Akan tetapi, Budianti et al. (2018) menemukan bahwa leverage tidak berpengaruh terhadap agresivitas pajak. Berdasarkan penjelasan diatas, maka hipotesis pada penelitian ini adalah:

\section{$\boldsymbol{H}_{4} \quad$ : Leverage berpengaruh positif terhadap agresivitas pajak.}

\section{METODE PENELITIAN}

\section{A. Objek Penelitian, Jenis, Teknik Pengumpulan Data, dan Teknik Pengambilan Sampel}

Objek pada penelitian ini adalah laporan keuangan tahunan perusahaan manufaktur yang terdaftar di Bursa Efek Indonesia pada tahun 2015-2017. Penelitian ini menggunakan jenis data sekunder. Jenis penelitian ini merupakan penelitian kuantitatif, yaitu penelitian yang dalam pengumpulan data berupa angka-angka, yang kemudian dapat diukur dan diuji dengan metode statistik (Suroiyah dan Khairani, 2018). Metode pengumpulan data menggunakan metode dokumentasi dan studi pustaka. Teknik pengambilan sampel pada penelitian ini menggunakan nonprobabiliy sampling dengan purposive sampling, yang merupakan metode pemilihan sampel secara tidak acak dengan menggunakan kriteria tertentu. Kriteria pengambilan sampel antara lain:

1. Perusahaan manufaktur yang terdaftar di Bursa Efek Indonesia pada tahun 2015-2017.

2. Perusahaan manufaktur yang menerbitkan laporan tahunan dan laporan keuangan yang diaudit dari tahun 2015-2017. 
3. Perusahaan manufaktur yang memperoleh laba.

4. Perusahaan manufaktur yang memiliki data lengkap sesuai dengan pengukuran variabel penelitian.

B. Pengukuran Variabel Penelitian

\begin{tabular}{ll}
\hline \multicolumn{1}{c}{ Variabel } & \multicolumn{1}{c}{ Proxy atau Alat Ukur } \\
\hline Agresivitas Pajak (Fullerton, 1983) & ETR: $\frac{\text { Beban Pajak }}{\text { Laba Sebelum Pajak }} \times 100$ \\
$\begin{array}{l}\text { Kepemilikan Institusional } \\
\text { (Demsetz dan Lehn, 1985) }\end{array}$ & KI: $\frac{\text { Jumlah Saham Institusi }}{\text { Kumlah Saham yang Beredar }} \times 100$ \\
$\begin{array}{l}\text { Kepemilikan Manajerial } \\
\text { (Demsetz dan Lehn, 1985) }\end{array}$ & KM: $\frac{\text { Jumlah Saham Manajerial }}{\text { Kumlah Saham yang Beredar }} \times 100$ \\
$\begin{array}{l}\text { Kepemilikan Publik } \\
\text { Leverage (De Jong dan Dijk, 1998) }\end{array}$ & KP: $\frac{\text { Jumlah Saham Publik }}{\text { Jumlah Saham yang Beredar }} \times 100$ \\
\hline
\end{tabular}

C. Teknik Pengolahan dan Analisis Data

Teknik pengolahan data dilakukan dengan uji statistik deskriptif untuk menampilkan informasi-informasi yang terkandung dalam data, uji asumsi klasik sebagai syarat dilakukannya analisis regresi melalui uji normalitas, uji autokorelasi, uji multikolinieritas, dan uji heteroskedastisitas. Pengujian hipotesis menggunakan regresi linier berganda, yaitu untuk mengetahui pengaruh variabel independen terhadap variabel dependen. Selain itu, untuk memperoleh hasil regresi yang akurat, maka perlu dilakukan uji yang lain, yaitu uji koefisien determinasi, uji F, dan uji t. Model regresi yang digunakan dalam penelitian ini adalah:

$$
\mathrm{AP}=\alpha+\beta_{1 .} \mathrm{KI}+\beta_{2 .} \mathrm{KM}+\beta_{3 .} \cdot \mathrm{KP}+\beta_{4 .} \mathrm{L}+\mathrm{e}
$$

Keterangan:

$\begin{array}{ll}\mathrm{AP} & =\text { Agresivitas Pajak } \\ \alpha & =\text { Konstanta } \\ \beta & =\text { Nilai Koefisien } \\ \mathrm{KI} & =\text { Kepemilikan Institusi } \\ \mathrm{KM} & =\text { Kepemilikan Manajerial } \\ \mathrm{KP} & =\text { Kepemilikan Publik } \\ \mathrm{L} & =\text { Leverage } \\ \mathrm{e} & =\text { Standar Error }\end{array}$

\section{HASIL DAN PEMBAHASAN}

\section{Gambaran Umum Objek Penelitian}

Berdasarkan pengumpulan data dengan menggunakan purposive sampling, didapat 33 perusahaan yang menjadi sampel dalam penelitian ini. Adapun kriteria dalam pemilihan sampel, yaitu: 
Tabel 1 Rincian Jumlah Data Penelitian

\begin{tabular}{clcccc}
\hline \multirow{2}{*}{ No } & \multicolumn{1}{c}{ Keterangan } & \multicolumn{3}{c}{ Jumlah Perusahaan } & Jumlah \\
& \multicolumn{1}{c}{2015} & 2016 & 2017 & Data \\
\hline 1 & $\begin{array}{l}\text { Perusahaan manufaktur yang terdaftar di BEI } \\
\text { pada periode 2015-2017 }\end{array}$ & 143 & 144 & 153 & 440 \\
2 & $\begin{array}{l}\text { Perusahaan manufaktur yang menerbitkan } \\
\text { laporan tahunan dan laporan keuangan } \\
\text { konsolidasian pada periode 2015-2017 }\end{array}$ & 134 & 134 & 145 & 413 \\
$3 \quad \begin{array}{l}\text { Perusahaan manufaktur yang memperoleh laba } \\
\text { pada periode 2015-2017 }\end{array}$ & 66 & 84 & 79 & 229 \\
$4 \quad \begin{array}{l}\text { Perusahaan manufaktur yang memiliki data } \\
\text { lengkap (sesuai pengukuran variabel penelitian) }\end{array}$ & 33 & 33 & 33 & 99 \\
$\begin{array}{l}\text { Total data selama 3 periode } \\
\text { Data outlier } \\
\text { Total data yang bisa dilakukan pengujian }\end{array}$ & & & & 99 \\
\hline
\end{tabular}

2. Uji Statistik Deskriptif

Statistik deskriptif menampilkan informasi-informasi mengenai nilai maksimum, minimum, rata-rata (mean), dan standar deviasi. Sampel penelitian ini terdiri dari 33 perusahaan dengan periode tiga tahun (2015-2017) dengan jumlah sampel sebesar 88 .

Tabel 2 Hasil Uji Statistik Deskriptif

\begin{tabular}{cccccc}
\hline Variabel & N & Minimum & Maximum & Mean & Std. Deviation \\
\hline KI & 88 & 5,143 & 95,779 & 66,07330 & 17,876087 \\
KM & 88 & 0,001 & 38,009 & 6,62417 & 8,615917 \\
KP & 88 & 0,198 & 56,847 & 27,30461 & 14,564054 \\
L & 88 & 9,008 & 83,396 & 41,31742 & 19,031729 \\
AP & 88 & 5,691 & 49,897 & 25,54468 & 7,860346 \\
\hline
\end{tabular}

3. Uji Asusmsi Klasik

a. Uji Normalitas

Tabel 3 Hasil Uji Normalitas

One-Sample Kolmogorov-Smirnov Test

\begin{tabular}{cc}
\hline & Unstandardize Residual \\
\hline Asympototic Significance (2-tailed) & 0,101 \\
\hline
\end{tabular}

Berdasarkan Tabel 3, diketahui bahwa nilai Asympototic Significance 0,101 > $\alpha$ 0,05. Hal tersebut menunjukkan bahwa data pada penelitian ini telah berdistribusi normal, sehingga peneliti dapat melakukan pengujian selanjutnya.

b. Uji Autokorelasi

Tabel 4 Hasil Uji Autokorelasi

Durbin-Watson 2,195

Berdasarkan Tabel 4, nilai dW sebesar 2,195. Pada Tabel Durbin-Watson $\alpha$ 5\%, dengan $\mathrm{n}=88$ dan $\mathrm{k}=4$ diperoleh nilai $\mathrm{d} \mathrm{L}=1,5597$ dan $\mathrm{d} \mathrm{U}=1,7493$, sehingga nilai 4- $\mathrm{d} \mathrm{U}=2,2507$. Oleh karena itu, model pada penelitian ini tidak terjadi autokorelasi, karena nilai $\mathrm{dU}<\mathrm{dW}<4$-dU atau 1,5597 < $2,195<2,2507$. 
c. Uji Multikolinieritas

Tabel 5 Hasil Uji Multikolinieritas

\begin{tabular}{ccc}
\hline \multirow{2}{*}{ Variabel } & \multicolumn{2}{c}{ Collinearity Statistics } \\
& Tolerance & VIF \\
\hline KI & 0,216 & 4,620 \\
KM & 0,916 & 1,092 \\
KP & 0,215 & 4,655 \\
L & 0,870 & 1,150 \\
\hline
\end{tabular}

Berdasarkan Tabel 5, pada masing-masing variabel nilai tolerance $>0,1$ dan nilai VIF $<10$. Dapat diketahui bahwa variabel independen pada model penelitian ini tidak saling korelasi, sehingga model dikatakan baik dan dapat dilakukan pengujian selanjutnya.

d. Uji Heteroskedastisitas

Tabel 6 Hasil Uji Heteroskedastisitas

\begin{tabular}{ccc}
\hline Variabel & $\mathbf{t}$ & sig \\
\hline KI & 0,191 & 0,849 \\
KM & 0,811 & 0,420 \\
KP & 0,947 & 0,346 \\
L & 1,736 & 0,086 \\
\hline
\end{tabular}

Berdasarkan Table 6, hasil uji heteroskedastisitas dengan uji glejser dapat diketahui bahwa nilai signifikansi ketiga variabel independen $>0,05$, sehingga model tidak terjadi heteroskedastisitas.

4. Uji Hipotesis

a. Analisis Regresi

Tabel 7 Hasil Uji Regresi Linier Berganda

\begin{tabular}{|c|c|c|}
\hline \multirow{2}{*}{ Model } & \multicolumn{2}{|c|}{ Unstandardized Coefficients } \\
\hline & B & Std. Error \\
\hline (Constant) & 48,010 & 9,446 \\
\hline Kepemilikan Institusional & $-0,280$ & 0,098 \\
\hline Kepemilikan Manajerial & 0,002 & 0,002 \\
\hline Kepemilikan Publik & $-0,264$ & 0,120 \\
\hline Leverage & 0,076 & 0,046 \\
\hline
\end{tabular}

Berdasarkan Tabel 7, persamaan regresi dapat disusun sebagai berikut:

$$
\mathrm{AP}=48,010-0,280 \mathrm{KI}+0,002 \mathrm{KM}-0,264 \mathrm{KP}+0,076 \mathrm{~L}+\mathrm{e}
$$

b. $\quad$ jji F

Tabel 8 Hasil Uji F

\begin{tabular}{ccc}
\hline Model & F & Sig. \\
\hline Regression & 2,730 & 0,034 \\
\hline
\end{tabular}


Berdasarkan Tabel 8, terlihat nilai sig $0,034<\alpha(0,05)$, sehingga dapat disimpulkan bahwa variabel kepemilikan institusional, kepemilikan manajerial, kepemilikan publik, dan leverage secara bersama-sama berpengaruh terhadap agresivitas pajak.

c. Uji t

Tabel 9 Hasil Uji t

\begin{tabular}{cccc}
\hline Model & \multicolumn{2}{c}{ Unstandardized Coefficients } & Sig \\
\hline B & B & Std. Error & 5,083 \\
Kepemilikant) & 48,010 & 9,446 & 0,005 \\
Kepemilikan Manajerial & $-0,280$ & 0,098 & 0,501 \\
Kepemilikan Publik & 0,002 & 0,002 & 0,031 \\
Leverage & $-0,264$ & 0,120 & 0,102 \\
\hline
\end{tabular}

1) Hipotesis Pertama (H1)

Hipotesis pertama pada penelitian ini adalah kepemilikan institusional berpengaruh negatif terhadap agresivitas pajak. Berdasarkan Tabel 9, variabel kepemilikan institusional memiliki nilai sig $(0,005)<\alpha(0,05)$, sehingga hipotesis pertama diterima dan kepemilikan institusional berpengaruh terhadap agresivitas pajak.

2) Hipotesis Kedua (H2)

Hipotesis kedua pada penelitian ini adalah kepemilikan manajerial berpengaruh positif terhadap agresivitas pajak. Berdasarkan Tabel 9, variabel kepemilikan manajerial memiliki nilai sig $(0,501)>\alpha(0,05)$, sehingga hipotesis kedua ditolak dan kepemilikan manajerial tidak berpengaruh terhadap agresivitas pajak.

\section{3) Hipotesis Ketiga (H3)}

Hipotesis ketiga pada penelitian ini adalah kepemilikan publik berpengaruh negatif terhadap agresivitas pajak. Berdasarkan Tabel 9 , variabel kepemilikan publik memiliki sig $(0,031)<\alpha(0,05)$, sehingga hipotesis ketiga diterima dan kepemilikan publik berpengaruh terhadap agresivitas pajak.

4) Hipotesis Keempat (H4)

Hipotesis keempat pada penelitian ini adalah leverage berpengaruh positif terhadap agresivitas pajak. Berdasarkan Tabel 9, variabel leverage memiliki sig $(0,102)>\alpha(0,05)$, sehingga hipotesis kedua ditolak dan leverage tidak berpengaruh terhadap agresivitas pajak.

Tabel 10 Ringkasan Hasil Pengujian Hipotesis

$\mathrm{H}_{\mathrm{1}} \quad$ Kepemilikan institusional berpengaruh terhadap agresivitas pajak $\quad$ Diterima

$\mathrm{H}_{2} \quad$ Kepemilikan manajerial berpengaruh terhadap agresivitas pajak Ditolak

$\mathrm{H}_{3} \quad$ Kepemilikan publik berpengaruh terhadap agresivitas pajak $\quad$ Diterima

$\mathrm{H}_{4} \quad$ Leverage berpengaruh terhadap agresivitas pajak Ditolak

d. Koefisien Determinasi

Tabel 11 Hasil Uji Koefisien Determinasi

\begin{tabular}{ccc}
\hline Model & R Square & Adjusted R Square \\
\hline 1 & 0,116 & 0,074 \\
\hline
\end{tabular}


Berdasarkan Tabel 11, nilai Adjusted R Square adalah 0,074. Dari hasil tersebut, dapat diketahui bahwa variabel kepemilikan institusional, kepemilikan manajerial, kepemilikan publik, dan leverage dapat menjelaskan variabel agresivitas pajak sebesar 7,4\%. Sementara itu, sisanya $92,6 \%$ dijelaskan oleh variabel lain yang tidak diteliti.

\section{Pembahasan}

\section{Pengaruh Kepemilikan Institusional terhadap Agresivitas Pajak}

Berdasarkan hasil uji yang dilakukan, diketahui bahwa hipotesis pertama (H1) diterima. Hasil menunjukkan kepemilikan institusional berpengaruh negatif terhadap agresivitas pajak. Hasil penelitian ini mendukung penelitian Atami et al. (2017) dan Nugroho dan Firmansyah (2017) yang menyatakan semakin banyak kepemilikan institusional, maka perusahaan semakin rendah melakukan pajak agresif. Penelitian ini tidak mendukung hasil penelitian Fadli (2016) yang menyatakan bahwa kepemilikan institusi tidak berpengaruh terhadap agresivitas pajak.

Berpengaruhnya kepemilikan institusional terhadap agresivitas pajak diduga karena kepemilikan dari institusi dapat mendorong manajemen untuk tidak melalukan tindakan pajak agresif. Kepemilikan institusional biasanya memiliki prosentase kepemilikan saham yang besar yaitu lebih dari 50\%, sehingga dengan besarnya kepemilikan tersebut dapat menjadikan pihak-pihak institusi mempunyai andil yang besar dalam memengaruhi pengambilan keputusan perusahaan. Kepemilikan institusional juga berhak memantau jalannya perusahaan, sehingga pihak ini dapat memaksa manajer untuk bertindak sesuai dengan tujuan perusahaan dan tidak bertindak mementingkan kepentingan pribadi, seperti mengurangi jumlah pajak perusahaan.

Manajer harus mempertimbangkan risiko yang akan terjadi kepada pemegang saham apabila perusahaan melakukan pengurangan pajak, sehingga dengan adanya kepemilikan institusional dapat mengurangi tidakan agresivitas pajak perusahaan (Ginting, 2016).

\section{Pengaruh Kepemilikan Manajerial terhadap Agresivitas Pajak}

Berdasarkan hasil uji yang dilakukan, diketahui bahwa hipotesis kedua (H2) ditolak. Hasil menunjukkan kepemilikan manajerial tidak berpengaruh terhadap agresivitas pajak. Hasil penelitian ini mendukung penelitian Hartadinata dan Tjaraka (2013) dan Novitasari et al. (2017) yang menyatakan kepemilikan manajerial tidak mempunyai pengaruh terhadap agresivitas pajak perusahaan. Penelitian ini tidak mendukung hasil penelitian Rohmansyah (2017) yang menyatakan bahwa kepemilikan manajerial berpengaruh positif terhadap agresivitas pajak.

Tidak berpengaruhnya kepemilikan manajerial terhadap agresivitas pajak diduga karena sangat kecilnya prosentase kepemilikan saham yang dimiliki oleh pihak manajemen perusahaan itu sendiri. Kepemilikan manajerial pada perusahaan sampel ini mayoritas memiliki prosentase kepemilikan saham yang kecil yaitu kurang dari 10\%. Menurut Prayogo dan Darsono (2015), pemilik saham terbesar menggambarkan pihak yang memegang kuat dalam voting Rapat Umum Pemegang Saham (RUPS). Karena kepemilikan manajerial lebih kecil dibandingkan dengan investor lain, maka pihak ini tidak cukup kuat untuk memengaruhi pengambilan keputusan perusahaan.

\section{Pengaruh Kepemilikan Publik terhadap Agresivitas Pajak}

Berdasarkan hasil uji yang dilakukan, diketahui bahwa hipotesis ketiga (H3) diterima. Hasil menunjukkan kepemilikan publik berpengaruh negatif terhadap agresivitas pajak. Hasil penelitian ini mendukung penelitian Puspita dan Harto (2014) yang menyatakan semakin banyak kepemilikan publik, maka semakin rendah tindakan penghindaran pajak perusahaan. Penelitian ini tidak mendukung hasil penelitian Oktaviana dan Wahidahwati (2017) yang menyatakan bahwa kepemilikan publik berpengaruh positif terhadap agresivitas pajak. 
Berpengaruhnya kepemilikan publik terhadap agresivitas pajak diduga karena masyarakat menginginkan perusahaan memiliki pendapatan tinggi yang nantinya dapat meningkatkan harga saham (Oktaviana dan Wahidahwati, 2017). Apabila pendapatan perusahaan tinggi maka laba perusahaan juga semakin tinggi. Laba perusahaan tinggi akan memengaruhi jumlah pajak yang dibayarkan yaitu juga semakin banyak. Oleh karena itu, kepemilikan saham oleh publik dapat menghambat manajemen dalam mengurangi pajak perusahaan (Prayogo dan Darsono, 2015). Selain itu, masyarakat juga megharapkan perusahaan untuk tidak melakukan penghindaran pajak. Masyarakat takut apabila dengan menghidari pajak, perusahaan akan terkena masalah yaitu nilai saham akan menurun, dan hal tersebut akan merugikan pemegang saham. Masyarakat juga berharap perusahaan membayarkan pajak dengan benar, karena hal tersebut berarti perusahaan telah berkontribsi terhadap pembangunan negara.

\section{Pengaruh Leverage terhadap Agresivitas Pajak}

Berdasarkan hasil uji yang dilakukan, diketahui bahwa hipotesis keempat (H4) ditolak. Hasil menunjukkan leverage tidak berpengaruh terhadap agresivitas pajak. Hasil penelitian ini mendukung penelitian Budianti et al. (2018), Azizah dan Kusmuriyanto (2016), dan Hartadinata dan Tjaraka (2013) yang menyatakan bahwa leverage tidak memiliki pengaruh terhadap agresivitas pajak. Penelitian ini tidak mendukung hasil penelitian Suroiyah dan Khairani (2018), dan Purwanto (2016) yang menyatakan bahwa leverage berpengaruh positif terhadap agresivitas pajak.

Tidak berpengaruhnya leverage terhadap agresivitas pajak diduga karena perusahaan tidak dapat memanfaatkan hutang untuk mengurangi jumlah pajak. Padahal jika perusahaan memiliki hutang yang tinggi, maka perusahaan tersebut akan diberikan insentif pajak berupa potongan bunga pinjama. Perusahaan sebagai debitur juga harus menyajikan laporan keuangan kepada kreditur. Pihak kreditur dapat memaksa debitur untuk melaporkan kinerjanya secara transparan, seperti laba, pendanaan dan pelaporan pajak perusahaan. Selain itu debitur tidak hanya wajib menyajikan laporan dalam jangka pendek, namun juga jangka panjang selama periode kredit. Laporan tersebut dapat membantu kreditur dalam menilai kinerja debitur dan prospek dimasa mendatang.

\section{KESIMPULAN}

Penelitian ini bertujuan untuk menguji dan memperoleh bukti empiris mengenai pengaruh kepemilikan saham dan leverage terhadap agresivitas pajak perusahaan pada perusahaan manufaktur yang terdaftar di BEI tahun 2015-2017. Berdasarkan hasil analisis data yang dilakukan, maka dapat ditarik kesimpulan dari penelitian ini adalah kepemilikan institusional berpengaruh negatif signifikan terhadap agresivitas pajak perusahaan. Kepemilikan manajerial tidak berpengaruh terhadap agresivitas pajak perusahaan. Kepemilikan publik berpengaruh negatif signifikan terhadap agresivitas pajak perusahaan. Leverage tidak berpengaruh terhadap agresivitas pajak perusahaan.

Saran untuk penelitian selanjutnya diharapkan menambah variabel independen lain yang berpotensi berpengaruh terhadap agresivitas pajak seperti kualitas audit, komisaris independen, kompensasi rugi fiskal, koneksi politik, komite audit. Untuk objek penelitian, peneliti selanjutnya diharapkan dapat meneliti pada perusahaan sub sektor lain yang terdaftar di Bursa Efek Indonesia, tidak hanya pada perusahaan manufaktur saja. Untuk periode pengamatan, peneliti selanjutnya diharapkan memperpanjang periode pengamatan dan menggunakan periode terbaru.

\section{DAFTAR PUSTAKA}

Astuti, T. P., \& Aryani, Y. A. (2016). Tren Penhindaran Pajak Perusahaan Manufaktur di

Indonesia yang Terdaftar di BEI Tahun 2001-2014, Jurnal Akuntansi, 20(3), 375-388. 
Atami, A. G., Basri, Y. M., \& Kurnis, P. (2017). Pengaruh Corporate Governance, Manajemen Laba, dan Capital Intensity terhadap Agresivitas Pajak (Studi Empiris pada Perusahaan Manufaktur yang Terdaftar di BEI Periode 2013-2015), JOM Fekon, 4(1).

Atari, J. (2016). Pengaruh Kepemilikan Manajerial, Kepemilkan Institusional, dan Kebijakan Hutang terhadap Tax Aggressive, JOM Fekon, 3(1).

Azizah, N., \& Kusmuriyanto. (2016). The Effect of Related Party Transaction, Leverage, Commissioners and Directors Compensation on Tax Aggressiveness, Accounting Analysis Journal, 5(4).

Budianti, I., Nazar, M. R., \& Kurnia. (2018). Pengaruh Return on Assets (ROA), Leverage (DER), Komisaris Independen dan Ukuran Perusahaan terhadap Agresivitas Pajak, eProceeding of Management, 5(2), 2368.

De Jong, A., \& Dijk, R. (1998). Determinants of Leverage and Agency Problems, CentER Discussion Paper, 82 (Juli).

Demsetz, H., \& Lehn, K. (1985). The Structure of Corporate Ownership: Causes and Consequences, Journal of Political Economy, 93(6), 1155-1177.

Direktorat Jenderal Pajak Kementerian Keuangan, Seri PPh - Subjek Pajak Penghasilan, http://www.pajak.go.id/content/seri-pph-subjek-pajak-penghasilan. Diakses tanggal 18 Februari 2019 pk 11.48 WIB

Fadli, I. (2016). Pengaruh Likuiditas, Leverage, Komisaris Independen, Manajemen Laba dan Kepemilikan Institusional terhadap Agresivitas Pajak Perusahaan (Studi Pada Perusahaan Manufaktur yang Terdaftar di Bursa Efek Indonesia Periode 2011-2013), JOM Fekon, 3(1).

Frank, M. M., Lynch, L. J., \& Rego, S. O. (2009). Tax Reporting Aggressiveness and Its Relation to Aggressive Financial Reporting, The Accounting Review, 84(2).

Fullerton, D. (1983). Which Effective Tax Rate?, National Bureau of Economic Research, 1123.

Ginting, S. (2016). Pengaruh Corporate Governance dan Kompensasi Rugi Fiskal terhadap Penghindaran Pajak dengan Ukuran Perusahaan sebagai Variabel Moderating, Jurnal Wira Ekonomi Mikroskil, 6(2).

Hadi, J., \& Mangoting, Y. (2014). Pengaruh Struktur Kepemilikan Dan Karakteristik Dewan terhadap Agresivitas Pajak, Tax \& Accounting Review, 4(2).

Hartadinata, O. S., \& Tjaraka, H. (2013). Analisis Pengaruh Kepemilikan Manajerial, Kebijakan Hutang, dan Ukuran Perusahaan terhadap Tax Aggressiveness pada Perusahaan Manufaktur di Bursa Efek Indonesia Periode Tahun 2008-2010, Jurnal Ekonomi dan Bisnis, 23(3).

Herdianti, W., \& Husaini, A. (2018). Pengaruh Leverage, Kepemilikan Manajerial dan Kepemilikan Institusional terhadap Keputusan Investasi (Studi Pada Perusahaan Sektor Industri Barang Konsumsi Yang Terdaftar Di Bursa Efek Indonesia Peiode 2010-2016), Jurnal Administrasi Bisnis (JAB), 55(2).

Jensen, M. C., \& Meckling, W. H. (1976). Theory oh the Firm: Managerial Behavior, Agency Cost and Ownership Structure, Journal of Financial Economics, 3(4), 305-360.

Kompas.com, Coca-Cola Diduga Akali Setor Pajak, https://bisniskeuangan.kompas.com/read/2014/06/13/1135319/CocaCola.Diduga.Akali.Setoran.Pajak. Diakses tanggal 22 November 2018 pk 21.47 WIB.

Mardiasmo. (2009). Perpajakan, Edisi 16, Andi, Yogyakarta.

Naim, A., \& Fuad, R. (2000). Analisis Hubungan antara Kelengkapan Pengungkapan Laporan Keuangan dengan Struktur Modal dan Tipe Kepemilikan Perusahaan, Jurnal Ekonomi dan Bisnis Indonesia, 15 (1-4).

Ngadiman, \& Puspitasari, C. (2014). Pengaruh Leverage, Kepemilikan Institusional, dan Ukuran Perusahaan terhadap Penghindaran Pajak (Tax Avoidane) pada Perusahaan Sektor Manufaktur yang Terdaftar di Bursa Efek Indonesia 2010-2012, Jurnal Akuntansi, XVIII (3), 408-421.

Novitasari, S., Ratnawati, V., \& Silfi, A. (2017). Pengaruh Manajemen Laba, Corporate Governance, dan Intensitas Modal terhadap Agresivitas Pajak Perusahaan (Studi Empiris 
pada Perusahaan Property dan Real Estate yang Terdaftar di BEI Periode Tahun 20102014), JOM Ferkon, 4(1).

Nugroho, S. A., \& Firmansyah, A. (2017). Pengaruh Financial Distress, Real Earnings

Management dan Corporate Governance terhadap Tax Aggressiveness, Journal of Business Administration, 1(2), 17-36.

Oktaviana, L. L., \& Wahidahwati. (2017). Pengaruh Kepemilikan Saham dan Corporate Social Responsibility terhadap Agresivitas Pajak, Jurnal Ilmu dan Riset Akuntansi, 6(11).

Prayogo, K. H., \& Darsono. (2015). Fakotr-Faktor yang Berpengaruh terhadap Penghindaran Pajak Perusahaan, Diponegoro Journal of Accounting, 4(3), 1-12.

Purwanto, A. (2016). Pengaruh Likuiditas, Leverage, Manajemen Laba, dan Kompensasi Rugi Fiskal terhadap Agresivitas Pajak Perusahaan pada Perusahaan Pertanian dan Pertambangan yang Terdaftar di Bursa Efek Indonesi Periode 2011-2013, JOM Ferkon, 3(1).

Puspita, S. R., \& Harto, P. (2014). Pengaruh Tata Kelola Perusahaan terhadap Penghindaran Pajak, Diponegoro Journal of Accounting, 3 (2), 1-13.

Rohmansyah, B. (2017). Determinan Kinerja Perusahaan terhadap Agresivits Pajak (Studi Pada Perusahaan Sektor Perbankan yang terdaftar di Bursa Efek Indonesia Periode 2010-2014), Competitive, 1(1).

Sari, I., Marheni, \& Yanfi. (2017). Analisis Pengaruh Ukuran Perusahaan, Struktur Kepemilikan Publik, Komite Audit, dan Leverage terhadap Penerapan Konservatisme Akuntansi, Jurnal Ilmiah Akuntansi Bisnis \& Keuangan (JIABK), 13(2).

Suara.com, Fitra: Setiap Tahun, Penghindaran Pajak Capai Rp 110 Triliun, https://www.suara.com/bisnis/2017/11/30/190456/fitra-setiap-tahun-penghindaran-pajakcapai-rp110-triliun. Diakses tanggal 15 Mei 2018 pk 20.14 WIB.

Suroiyah \& Khairani, S. (2018). Pengaruh Pengungkapan Corporate Social Responsibility (CSR), Ukuran Perusahaan, Profitabilitas, Leverage dan Likuiditas terhadap Agresivitas Pajak (Studi Empiris pada Perusahaan Industri Dasar dan Kimia yang Terdaftar di Bursa Efek Indonesia Tahun 2014-2016). MDP Business School.

Undang-Undang Nomor 16 Tahun 2009 tentang Ketentuan Umum dan Tata Cara Perpajakan. 